Article

\title{
The Slow Displacement of Smallholder Farming Families: Land, Hunger, and Labor Migration in Nicaragua and Guatemala
}

\author{
Lindsey Carte ${ }^{1, *}$, Birgit Schmook ${ }^{2, *} \mathbb{( \mathbb { D }}$, Claudia Radel $^{3} \mathbb{1}$ and Richard Johnson ${ }^{4}$ \\ 1 Núcleo de Ciencias Sociales y Humanidades, Universidad de la Frontera, Temuco 4780000, Chile \\ 2 Departamento de Conservación de la Biodiversidad, El Colegio de la Frontera Sur (ECOSUR) Chetumal, \\ Chetumal 77014, Mexico \\ 3 Department of Environment and Society, Utah State University, Logan, UT 84322, USA; \\ claudia.radel@usu.edu \\ 4 School of Geography and Development, University of Arizona, Tucson, AZ 85721, USA; \\ rljohnson@email.arizona.edu \\ * Correspondence: lindsey.carte@ufrontera.cl (L.C.); bschmook@ecosur.mx (B.S.)
}

Received: 6 March 2019; Accepted: 24 May 2019; Published: 3 June 2019

\begin{abstract}
Smallholders worldwide continue to experience processes of displacement from their lands under neoliberal political-economic governance. This displacement is often experienced as "slow", driven by decades of agricultural policies and land governance regimes that favor input-intensive agricultural and natural resource extraction and export projects at the expense of traditional agrarian practices, markets, and producers. Smallholders struggle to remain viable in the face of these forces, yet they often experience hunger. To persist on the land, often on small parcels, families supplement and finance farm production with family members engaging in labor migration, a form of displacement. Outcomes, however, are uneven and reflect differences in migration processes as well as national and local political economic processes around land. To demonstrate "slow displacement", we assess the prolonged confluence of land access, hunger, and labor migration that undermine smallholder viability in two separate research sites in Nicaragua and Guatemala. We draw on evidence from in-depth interviews and focus groups carried out from 2013 to 2015, together with a survey of 317 households, to demonstrate how smallholders use international labor migration to address persistent hunger, with the two cases illuminating the centrality of underlying land distribution questions in labor migration from rural spaces of Central America. We argue that smallholder farming family migration has a dual nature: migration is at once evidence of displacement, as well as a strategy for families to prolong remaining on the land in order to produce food.
\end{abstract}

Keywords: migration; land; food security; displacement; Nicaragua; Guatemala

\section{Introduction}

Members of rural Central American families are regularly faced with the decision to leave their communities to search for work abroad [1,2]. The root causes of these individuals' migration are complex, with insufficient land access as one the most pressing underlying causes [3,4]. Farming families are often unable to produce or buy enough food, which renders them food insecure $[5,6]$. The interlinking factors of hunger and limited land access underpin many decisions to migrate. In this article, we explore the nexus between land, food insecurity, and international migration in two locations in Guatemala and Nicaragua. In both countries, decades of agricultural policies and land governance regimes favoring export agriculture and natural resource extraction have concentrated arable lands, directly displacing some small-scale farming families from lands [7-12], but also setting 
off processes leading to a more general "slow displacement" of people from these rural places and from agricultural livelihoods.

Our study draws on in-depth interviews and focus groups that we carried out from 2013 to 2015, together with a survey of 317 households, at two rural sites in Guatemala (Caballo Blanco) and in Nicaragua (Somotillo). Rural residents in both countries heavily rely on small-scale agricultural production to secure food and livelihoods but are failing to achieve food security. To attempt to persist on the land, often on small parcels, families supplement and finance farm production with family members engaging in labor migration. Outcomes, however, are uneven and reflect differences in migration processes as well as national and local political economic processes around land.

Building on the concept of "slow violence", [13], which forwards a nuanced, long-term understanding of violence, we argue that structural, political-economic conditions are provoking a kind of displacement from the land that is unfolding slowly over years-a "slow displacement". While displacements from the land and forced mobility in general may be reduced to a fixed place, time, and action, viewing both phenomena as processes facilitates drawing connections and a fuller understanding of consequences.

In the study communities, displacement from the land does not occur at a definite point in time, yet unfolds over years and in some cases across generations. Slow displacement from the land, with shrinking land access, yields consequences including the truncated ability to engage in small-scale agriculture leading to hunger and ultimately migration. In this context, migration is at once evidence of displacement, as well as a strategy for families to prolong remaining on the land to produce food.

\section{Slow Displacement from the Land}

Bakewell argues that "[t]he process of displacement remains largely outside the realm of social scientific theory" [14] (p. 21). With regards to rural mobility, displacement has been used to describe involuntary migration after natural disasters [15] and climate change [16]; eviction for state projects, such as conservation areas [17]; and land expropriation [18], among others. Forced migration is also described as displacement, but is generally discussed in relation to conflict, war, and more recently, climate change. The literature on displacement as eviction or forced migration generally conceptualizes displacement as forced removal due to a singular cause (disaster or war, for example), occurring at a specific point in time.

Other literature describes forced migration as a displacement from livelihoods as a result of uneven development. Delgado Wise, Covarrubias, and Puentes maintain that uneven development has produced structural conditions leading to dispossession and exclusion. Labor migration in this case is "characterized by extreme vulnerability and exploitation [4] (p. 13)." In this sense, labor migrants share many of the characteristics of displaced peoples or refugees. The argument by Delgado Wise et al. draws the connection between structural changes to the rural economy and migration. Building on this argument, here, we propose a deepening of the theorization of displacement as a process, arguing for "slow displacement", drawing on Nixon's slow violence. Nixon first introduced the concept of "slow violence", in order to understand the true repercussions of environmental disasters. Violence tends to be viewed as a finite event with tangible, immediate consequences. However, Nixon proposes that the consequences of slow violence unfold gradually, "invisibly", and over many years [13]. This concept provides a powerful framework for exploring the processes of displacement, caused by insufficient land access, insufficient state support for smallholders, among other factors experienced in our study communities. In our research areas specifically, entrenched neoliberal agricultural policies that undermine small-scale producers' means to participate in markets as well as secure adequate access to land trigger slow displacement $[4,7,19]$. 


\section{Land and Displacement in Nicaragua and Guatemala}

Deep, historic inequality in land distribution in Nicaragua and Guatemala was a principal driver of both countries' civil wars. While the war's end in Nicaragua led to a 10-year revolutionary period, the formal end of conflict in both countries ushered in new eras of neoliberal reforms to the rural economy. Today, land concentration into the hands of a few seems to again be on the rise in both countries $[8,9]$. In both cases, forced migration due to war gave way to new waves of migration beginning in the 90s, in response to neoliberal restructuring, resulting in today's large-scale migrations [20]. In this section, we briefly summarize the political and economic factors driving the slow displacement of rural people from the land. Slow displacement is provoked by structural reforms mixed with long-held practices, leading to waves of emigration that provoke disjuncture from the land while simultaneously reinforcing connections for some families.

Currently and historically, Guatemala's economy has been based on an agro-export model that prioritizes extractive, large-scale production over small-scale, family production [10], and is linked to the historic poverty and inequality experienced in this country. Despite attempts to redistribute land during the Arevalo and Arbenz administrations of the 1940s and 1950s, which were halted by a military coup, Guatemala has never implemented an effective land reform to benefit the rural poor. Since colonial times national land distribution has remained extremely skewed and unequal. According to the US Agency for International Development, two-thirds of the agricultural land is dominated by $2.5 \%$ of the country's farms [21]. Land rights, along with poverty, deep ethnic and racial inequality, and a lack of attention to these issues by landed elites and the government drove the country's armed conflict between varying guerilla groups and the state spanning from 1960 to 1996. In 1996, the war ended with the signing of the Peace Accords, which included the adoption of a market-based land reform. The market-assisted land reform, however, failed to redistribute land-Guaster and Isaakson argue that the beneficiaries of the land reform were mostly the rural middle class, and that as of 2007 only $18.8 \%$ of applicants had received credit to purchase land [22]. Today, the agro-export model continues to dominate, with extractivist production of sugar cane, African palm, and rubber re-concentrating land [9].

Forty-nine percent of Guatemala's population is rural; however, landlessness among rural dwellers is widespread. Residents rely on semi-subsistence production of maize for food security, yet $27 \%$ of rural dwellers do not own land, and instead must rent or borrow land if they wish to produce [21]. Average landholdings have been shown to be insufficient to meet basic subsistence needs [22]. The resulting rural poverty and hunger is a key driver of migration from Guatemala's rural spaces north to the United States.

The war in Guatemala eventually produced between 500,000 and 1.5 million displaced people. The later years of armed conflict spurred migration to the USA, migration that then remained in place and grew in the context of post-conflict neoliberalism and the failure of the state to address the underlying structural inequalities. In 2015, there were 928,000 Guatemalan immigrants residing in the USA [23].

Although Nicaragua's path diverged sharply from Guatemala's after the Sandinistas toppled the Somoza dictatorship in 1979, rural residents continue to struggle with poor land access, poverty, and hunger as well. After Somoza's removal, the new Sandinista government initiated land reform, expropriating largely the Somoza family's sizeable landholdings across the country. The expropriated land was divided and given to cooperatives formed by landless 'campesinos'. Cooperatives were provided with ample credit, machinery, and technical support. As the US-funded Contra War debilitated the Sandinistas, enthusiasm for the revolutionary government declined. In 1990, Violeta Chamorro was elected president, ushering in neoliberal reforms to the economy that made the maintenance of rural cooperatives difficult and led many to subdivide and sell lands-leaving some rural dwellers landless again. The latest data available suggest that the richest $9 \%$ of landowners hold $56 \%$ of farmland in the country, while an estimated $38 \%$ of the rural population owns no land at all [24]. Many small-landholders also lack official titles to their land, or in some cases multiple claims exist for 
certain parcels [25]. In 2001, despite the gains of the Sandinista Revolution, smallholders had about the same amount of access to land as they did before the revolution [26]. Since then, the number of mid-sized farms has grown, with smallholders still lacking access [7].

Similar to Guatemala, Nicaragua encourages the commercial, export-oriented growth of the agricultural sector. The end of the revolution in 1990 initiated the deregulation of agricultural markets, and disassembled state credit and extension services. This model continues today under the Ortega regime, even though the government has created social programs and some supports for small-scale farmers [7]. Martí i Puig and Baumeister argue that the Ortega government, which claims to be socialist, has coopted the rural poor with targeted assistance, rather than addressing rural poverty through structural reforms [7]. Aguilar-Støen posits that, currently, Nicaragua is undergoing a re-concentration of land, with the growth of neo-extractivist agriculture, including sugar cane, peanuts, and cattle ranching [11].

The history of contemporary Nicaraguan migration, like Guatemalan migration, began during the country's civil war, when official and non-officially recognized refugees fled to Costa Rica, Honduras or the United States. Migration, especially to Costa Rica, intensified with the restructuring of the economy in the early 1990s and again after Hurricane Mitch devastated the region in 1998. Unlike Guatemala, Nicaraguans in large part migrate to neighboring countries, like Costa Rica and El Salvador, making South-South migration, rather than South-North migration, a key livelihood strategy.

Hunger is intrinsically linked to poverty, which in both countries is especially a rural problem. In Nicaragua, for example, with about half of the population living in rural areas, $25 \%$ of the households are classified as extremely poor and suffer food insecurity [27]. In Guatemala, poverty is reported to be very high-in 2014, 59.3\% of the population lived in poverty [28]. More than half (52\%) of the indigenous population, most of which lives in rural areas, is affected by poverty. The experience of food insecurity, or hunger, in Caballo Blanco and Somotillo reflects these wider rural patterns in Guatemala and Nicaragua, as our study results below demonstrate.

\section{Study Sites and Methods}

The villages of the study site in Nicaragua are located in the northern part of the country in the municipality of Somotillo, located in the low lying, coastal department of Chinandega, bordering Honduras (See Figure 1). Somotillo is part of the so-called "dry corridor", which covers approximately $34 \%$ of the national territory and where $80 \%$ of the country's population lives [29]. Over the last five decades, the climate in this region is becoming drier, with less frequent but more intense and unpredictable rains (see [28,30]). The population is mainly made up of 'mestizos' -or people of mixed indigenous and European descent.

The villages in the aldea of Caballo Blanco in the Guatemala study site are located in the Pacific lowland department of Retalhuleu (See Figure 1). Climate and soil conditions for agricultural production are generally good, with a mixed system of large-scale commercial sugar cane and cattle ranching and smallholder maize production. Retalhuleu has a short but intense dry season and experiences rain during most months, with average annual rainfall of $3154 \mathrm{~mm}$. The population in Caballo Blanco mostly identifies as non-indigenous 'ladino', although many of the original and contemporary settlers include members of both K'iche and Mam Maya indigenous groups, who themselves were displaced from Guatemala's western highlands and came to Caballo Blanco in search of land.

Field research was conducted in both Nicaragua and Guatemala between 2013 and 2015. We carried out in-depth interviews, focus groups, and household surveys to collect data on the themes of agriculture, land tenure, migration, and food security, among other topics. We surveyed random samples of households drawn from community censuses identifying all households in each community and the migration status of each household. A stratified sampling method was used to ensure sufficient participation of both migrant and non-migrant households. In Nicaragua, this resulted in 121 households surveyed across six small villages. In Guatemala, we surveyed 196 households in five Caballo Blanco villages. 
The qualitative interviews and focus groups both deepen and broaden our understanding of the same themes covered in the household survey. In-depth interviews were carried out with both survey participants and non-survey participants, using a snow-ball/purposive sampling technique. In total, we conducted 20 interviews at the Nicaragua site, and 17 interviews at the Guatemala site. We organized small focus groups in select communities in both countries. The focus groups used a cross between traditional focus group discussion techniques and more participatory research methods-such as making use of visuals, timelining, and brainstorming, in order to respect local knowledge and practices. In total, we conducted two "dynamic" focus groups in Nicaragua and four in Guatemala, with groups of women and men and mixed groups, with five to 15 participants each.
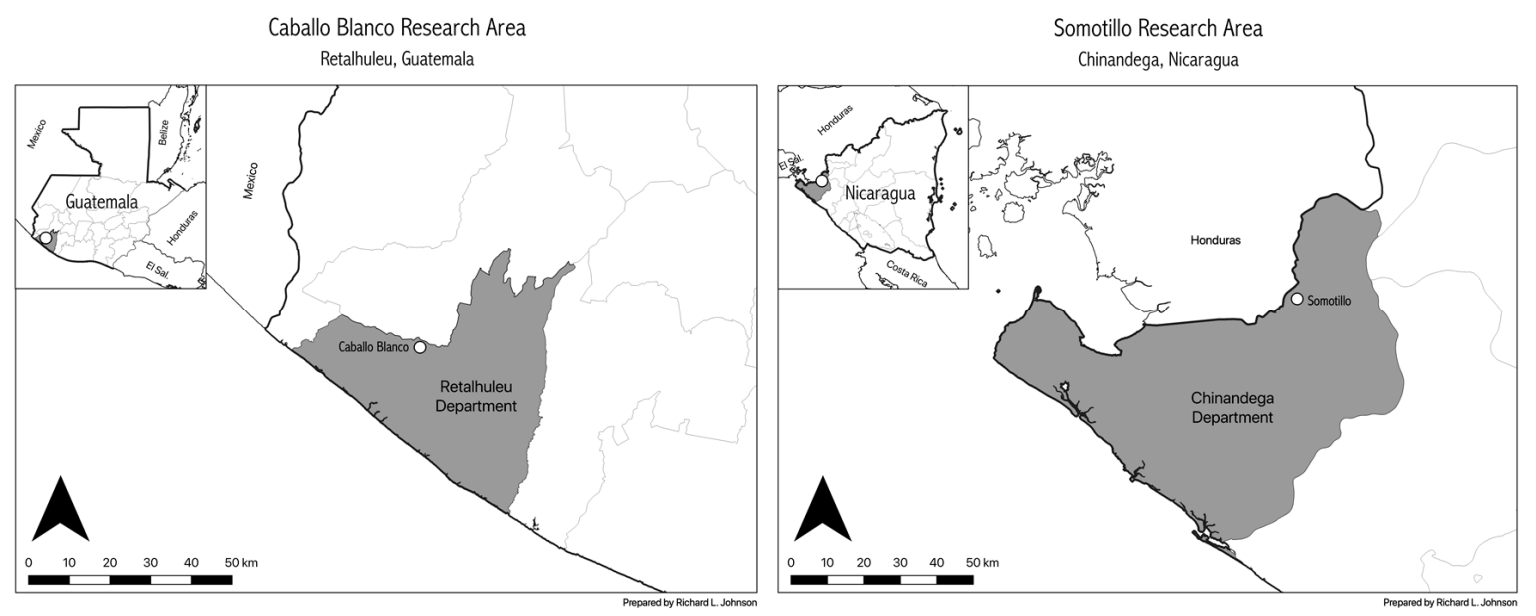

Figure 1. Study Sites.

The resultant qualitative and quantitative datasets were analyzed separately, as well as in conversation with each other. We used bivariate statistical analyses to assess differences between migrant and non-migrant households. For categorical variables, this consisted of chi-squared tests to evaluate a null hypothesis of no difference between household types, while for continuous variables this consisted of $t$-tests for differences in means. We conducted all statistical analyses using the software package SPSS. The bivariate statistical analyses, used on their own, do not reveal cause-and-effect relationships; however, their use in conjunction with robust qualitative data analysis provide strong evidence for understanding the relationships among migration, land, and hunger in the context of our case studies. Qualitative interviews were transcribed and subsequently processed using a thematic coding method. Coding was facilitated by Dedoose qualitative analysis software. Interview transcripts were read, coded, and then analyzed based on patterns and themes that emerged during the coding process. We integrated across the datasets through an iterative process by which hypotheses emerged from qualitative data analysis and were then tested using the survey data and survey data analysis results identified relationships for further coding and exploration using interview and focus group data.

\section{Results and Discussion: Slow Displacement from the Land and Widespread Food Insecurity}

In the following section, we present findings from our qualitative interviews and ethnographic research, as well as relevant household survey data, to highlight community members' experience of slow displacement from the land, and their perceptions of how migration intersects with land and food production in both Nicaragua and Guatemala. 


\subsection{Guatemala: Extractivism and Tightening Land Markets}

Even though $49.3 \%$ of the country's population is rural and depends on small-scale agriculture for food security, land in Guatemala is highly concentrated in the hands of a few elite families [31]. Before being subdivided and given to campesinos beginning in the 1950s, Caballo Blanco was a large landholding. Tracts of land were distributed to settlers, many hailing from the highlands and looking for the opportunity to obtain land. Today, most community members continue to participate in agriculture, relying on semi-subsistence cultivation during the rainy seasons and wage labor on nearby plantations during the dry season. Semi-subsistence production consists primarily of maize, for both household consumption and market, and sesame as a cash crop. Yet, access to land to produce is hard to come by. On the one hand, over generations, the size of family land holdings has shrunk as families grow and lands are divvied up among members through customary systems of inheritance. On the other hand, there are few opportunities to acquire land outside of what residents already hold and land for sale is generally too expensive for locals to afford due to land price inflation. The average land holding for sampled households are truly miniscule (see Table 1), with $77 \%$ of non-migrant households owning an average of 0.3 hectares each.

Table 1. Land Access in the Case Study Communities.

\begin{tabular}{|c|c|c|c|c|c|c|}
\hline & \multicolumn{3}{|c|}{ Somotillo, Nicaragua; $\mathbf{n}=121$} & \multicolumn{3}{|c|}{ Caballo Blanco, Guatemala; n = 196} \\
\hline Households with land holding & $79 \%$ & $93 \%$ & $p=0.027$ & $77 \%$ & $96 \%$ & $p=0.000$ \\
\hline Mean land holding (ha) & 7.9 & 11.5 & $p=0.248$ & 0.3 & 0.6 & $p=0.031$ \\
\hline Mean rented land (ha) & 1.4 & 1.2 & $p=0.590$ & 1.27 & 1.61 & $p=0.429$ \\
\hline Median rented land (ha) & 1.4 & 1.1 & - & 0.70 & 0.70 & - \\
\hline
\end{tabular}

* Migrant households are defined as those households with a member away in another country at the time of the survey. Means and medians are only for those holding/renting land (they exclude cases where value is 0 ).

Hunger in Caballo Blanco is widespread. Farmers here cultivate maize largely during one growing season, with a harvest in August/September, and afterwards, cultivate sesame as a cash crop in the same fields, for harvest in November/December. We asked all surveyed households to report food availability over the last 12 months (see Table 2). The literature on food security distinguishes between food availability, meaning in the market, and food access. Here, however, we refer to "food availability" as the food available within the home as a product of all household entitlements. The responses demonstrate that little food is available to many households throughout the year, with March and April (the apex of the dry season) being the most food-scarce months when between 71 and 85 percent of families reported poor availability or complete scarcity. In discussing these survey results with community members, participants pointed out that April is when wage labor opportunities on the cane plantations also end. The survey also asked respondents to report whether or not a member of the household had skipped a meal or had gone to bed hungry due to insufficient food in the last four weeks. For the non-migrant households, $17 \%$ reported a family member had skipped a meal and $32 \%$ reported a family member had gone to bed hungry. Migrant households reported lower rates, with 7\% and $22 \%$, respectively. 
Table 2. Hunger in the Case Study Communities.

\begin{tabular}{|c|c|c|c|c|c|c|}
\hline & \multicolumn{3}{|c|}{ Somotillo, Nicaragua $n=121$} & \multicolumn{3}{|c|}{ Caballo Blanco, Guatemala n = 196} \\
\hline & $\begin{array}{l}\text { Non-Migrant } \\
\quad(n=65)\end{array}$ & $\begin{array}{l}\text { Migrant * } \\
(\mathrm{n}=56)\end{array}$ & $\begin{array}{l}\text { Significance } \\
\text { (Chi-Square) }\end{array}$ & $\begin{array}{l}\text { Non-Migrant } \\
\quad(\mathrm{n}=88)\end{array}$ & $\begin{array}{l}\text { Migrant* } \\
(\mathrm{n}=108)\end{array}$ & $\begin{array}{l}\text { Significance } \\
\text { (Chi-Square) }\end{array}$ \\
\hline \multicolumn{7}{|c|}{ Last 4 weeks, household member } \\
\hline Skipped a meal & $17 \%$ & $21 \%$ & $p=0.529$ & $17 \%$ & $7 \%$ & $p=0.037$ \\
\hline Went to bed hungry & $11 \%$ & $7 \%$ & $p=0.491$ & $32 \%$ & $22 \%$ & $p=0.001$ \\
\hline \multicolumn{7}{|c|}{ Poor availability or complete scarcity of food in the home } \\
\hline January & $12 \%$ & $5 \%$ & $p=0.185$ & $67 \%$ & $55 \%$ & $p=0.077$ \\
\hline February & $42 \%$ & $34 \%$ & $p=0.390$ & $82 \%$ & $66 \%$ & $p=0.012$ \\
\hline March & $77 \%$ & $57 \%$ & $p=0.020$ & $85 \%$ & $71 \%$ & $p=0.020$ \\
\hline April & $86 \%$ & $73 \%$ & $p=0.075$ & $83 \%$ & $72 \%$ & $p=0.076$ \\
\hline May & $86 \%$ & $79 \%$ & $p=0.272$ & $78 \%$ & $66 \%$ & $p=0.051$ \\
\hline June & $82 \%$ & $80 \%$ & $p=0.831$ & $72 \%$ & $48 \%$ & $p=0.001$ \\
\hline July & $83 \%$ & $75 \%$ & $p=0.274$ & $71 \%$ & $40 \%$ & $p=0.000$ \\
\hline August & $77 \%$ & $64 \%$ & $p=0.126$ & $64 \%$ & $33 \%$ & $p=0.000$ \\
\hline September & $82 \%$ & $68 \%$ & $p=0.082$ & $55 \%$ & $20 \%$ & $p=0.000$ \\
\hline October & $74 \%$ & $66 \%$ & $p=0.351$ & $51 \%$ & $21 \%$ & $p=0.000$ \\
\hline November & $26 \%$ & $23 \%$ & $p=0.709$ & $44 \%$ & $55 \%$ & $p=0.000$ \\
\hline December & $6 \%$ & $5 \%$ & $p=0.852$ & $40 \%$ & $19 \%$ & $p=0.002$ \\
\hline
\end{tabular}

* Migrant households are defined as those households with a member away in another country at the time of the survey.

Food scarcity in the home reflects overall poverty in Caballo Blanco and the inability of families to grow sufficient amounts or access food through other means. Land access is essential for production, and although research participants perceive their yields to be low, they struggle to access and cultivate more land to make up for these low yields. Participants cite two major reasons for their difficulty in accessing land for food cultivation: sugar cane production's demand for land by the neighboring plantations and the insertion of remittances into community markets. Recently, large-scale sugar cane production has expanded to estates bordering the Caballo Blanco communities. Before planting sugar monocultures, these estates largely engaged in cattle ranching. Ranching left portions of land unoccupied, allowing community members opportunities to rent or borrow parcels of land to cultivate maize, with the farmer leaving the stubble for cattle or planting grass after harvest as part of the arrangement with the landowner. When these neighboring estates began to lease their land to the sugar-cane 'ingenios' ${ }^{1}$, community members lost access. One small-scale farmer in his 40 s explained:

The problem is that some estates ('fincas') used to rent out their land, so people used to get more land at a lower price. But they [the ingenios] started to grab up those large extensions of land, since they offered to pay much more rent.

Migration is an important survival strategy for families as they are blocked from previous modes of land access and off-farm work opportunities continue to be few. Indeed, since land resources have become scarcer as a result of sugar cane production, land rents have increased. Participants emphasized that families that receive remittances have acquired land and also have an easier time affording the high rents. Ninety-six percent of migrant households in our sample own land (Table 1), with the average holding double the size of the average holding of non-migrant households ( 0.6 ha versus 0.3 ha; $p=0.031$ ). Thirty-three percent of migrant households in our sample rent land. This difference further reinforces the perceived incentives to migrate for currently non-migrant households. One focus group participant, a woman in her 50s, explained:

One thing we've mentioned to each other [with respect to the reason why people migrate] is land rents—not everybody here has their own land. So the majority of them rent land, and in 
the past years, rents have really gone up. People are willing to pay [a lot] for a manzana ${ }^{2}$ of land to plant on.

As migrants send remittances to family members, these families are better prepared to pay higher rents. Some community members suggested that migrants actually are driving the high land prices, because they are willing and able to pay these high prices. As a result, non-migrant community members claim they are being shut out of the land markets. The household survey data indicate that households are most commonly paying rents of $\mathrm{GTQ}^{3} \$ 2000$ per manzana per production cycle, or the equivalent of about USD \$372 per hectare, but that some households pay as much as GTQ \$4800 per manzana, or USD $\$ 890$ per hectare.

With changing modes of access to land, people find themselves forced to migrate in order to survive and to afford food that is increasingly harder to produce:

... there's no way to live. That's what people [migrants] are looking for. They go so they can send their families food, even though they won't get rich or make good money, at least they'll [send money] for some beans.

Although the survey data demonstrate that migrant families in Caballo Blanco are better off with respect to both land access (Table 1) and the incidence of hunger (Table 2), a significant proportion of migrant households continues to struggle with food insecurity.

\subsection{Nicaragua: Working to Stay on the Land Through Subsistence Migration}

In Nicaragua, small-scale farmers cultivate maize, sorghum, and sesame, and raise cattle with the goal of securing enough food. Land to engage in these activities has never been easy to come by for residents. Nevertheless, participants attest to various factors that have complicated their access to land over the years, including re-concentration of land, higher prices, and changes in the way that poor families have traditionally been able to produce-by borrowing land or squatting on land.

During the Somoza dictatorship, most residents were landless, engaging in share-cropping arrangements, or borrowing land from larger landholders. After the overthrow of the Somoza dictatorship in 1979, the new Sandinista government began land reform. Ample credit and technical support were provided to cooperatives. However, with the end of the Sandinista government in 1990, neoliberal reforms were implemented that ended access to credit and other supports for cooperatives, leaving members with debts and forcing many to sell. The following focus group dialogue evidences how this process took place in the study communities:

Participant 1: The bank that financed our production at low interest rates was confiscated, and that's when we saw ourselves obligated to sell our property.

Participant 2: At least one of the cooperatives owed a lot of money and they had to sell the whole 100 manzanas that they had, [in order] to be able to pay.

Researcher: To whom did they sell?

Participant 2: To the same powerful people [who had it before], because a poor person wasn't going to buy 100 manzanas!

In this neoliberal context, there are several obstacles to semi-subsistence production, including lack of access to credit, no or few extension services, lack of sufficient land, and climate change [29]. By the time the cooperatives were broken up, according to one farmer, "The most anyone had was

\footnotetext{
0.7 hectares.

Guatemalan Quetzal, with an exchange rate of $1 \mathrm{GTQ}=0.13 \mathrm{USD}$.
} 
about 20 manzanas, the rest of us had 10 or 8 . When the cooperatives disappeared, each of us had a little piece of our own to be able to work-each one on his own little piece of land".

The survey data confirm that many Somotillo households hold land, but in small amounts (see Table 1), often not enough to meet household food needs. The non-migrant households in our sample who own land (79\%) own an average of 7.9 hectares, while the migrant households who own land $(93 \%)$ own an average of 11.5. More instructive might be the median land holdings-3.2 hectares for non-migrant families and 5.2 hectares for migrant families-as most sampled households own less than the average. Renting land is a necessity for many families, especially those who are the most land poor [29], and roughly a quarter of all households rent land. Community members who do not hold enough or own no land still need to grow food. Rent along with the cost of inputs-seed, fertilizer, pesticides and occasional labor-is one reason many families engage in temporary, repeated journeys to neighboring Costa Rica or El Salvador to work in the rural sector or in the service industry. As one frequent migrant to El Salvador put it, "If you don't have land, you have to go [migrate] to pay the rent and buy your fertilizer, and then you can work [the land], because if you just stay here, what are you going to use to buy your fertilizer? That's how it is".

This cultivation of the land is essential for household food access. In the Somotillo villages, as commonly observed in semi-subsistence agricultural communities, food availability follows a seasonal pattern tied to local production (Table 2). Fewer families produce during the first agricultural cycle, running roughly from May to August, due to rain variability. The main harvest is at the end of the second production cycle in November and December. As a result, November through January, food availability is reported as relatively good, while during other months, rates of families experiencing poor availability or total scarcity of food is as high as $86 \%$ (non-migrant households in April and May). In general, although the sampled migrant households reported somewhat lower incidences of hunger and food insecurity than did the sampled non-migrant households, the differences were not statistically significant. Thus, we conclude that migrant households tend to experience reasonably similar levels of food insecurity.

While migration helps some families to buy land, trips to El Salvador and Costa Rica tend to produce only enough income to support current small-scale production needs and, on average, do not allow families to become more food secure than their non-migrant neighbors. Community members in Somotillo also attest to currently high land prices that keep them from buying land, even with remittances. In this context, land rental becomes increasingly important. For migrant households in Somotillo, earnings from migration go directly into food production, bolstering semi-subsistence, small-scale agriculture, through the purchase of inputs and the payment of land rents. As we have argued elsewhere, this subsistence migration is used as a strategy to continue engagement in local agricultural systems, and to ultimately produce food [3], even as farming families continue to be food insecure.

\section{Conclusions}

We have argued that decades of agricultural policies and land governance regimes that favor agricultural and natural resource extraction and export, and that foster land concentration, drive slow displacement from the land. Experiences in Guatemala and Nicaragua have been different. In Nicaragua, there was at least some serious attempt (the 1979 Sandinista Revolution) to change land distribution, but the contemporary agro-export model, with accompanying land re-concentration, does not favor smallholders. In Guatemala, land reform was abandoned after the overthrow of Arbenz and later replaced with more "modest" market-based attempts at land redistribution that never helped most of the rural poor. The market-assisted reforms promoted by the World Bank did not achieve any meaningful land re-distribution, as mostly unsuitable lands have been offered on the land market [22]. Land holdings and land access in both of the case study sites are insufficient for long-term livelihood viability through farming. 
Our results suggest that although ownership of adequate amounts of land for production has never been widespread among community members, change in forms of access to land is slowly squeezing rural producers out of the countryside. Borrowing and renting are two important means by which community members both historically and currently access land. As opportunities to rent (much less borrow) become more limited, semi-subsistence food production is impacted negatively and food security deteriorates.

Current food insecurity, common across the study communities, reflects this reality of insufficient access to land. Limited land access is exacerbated by difficult access to other farming inputs. Thus, what our findings demonstrate for the Nicaraguan and Guatemalan sites is that slow displacement, manifest as this insufficient land for farming livelihoods, results in seasonal hunger. Our research suggests, as we also have demonstrated for the Somtillo case with findings published elsewhere [3], that migrant households in both sites employ earnings from migration to persevere in semi-subsistence agricultural production. While migration mitigates hunger for some migrant households, food insecurity persists for many families, even for many of those engaging in migration or receiving remittances. These Guatemala and Nicaragua case studies furthermore show that migration outcomes can be uneven and can reflect locational differences in migration processes, as well as the differences in national and local political economic processes around land. To further understand the relationship between migration and food security-related small-scale agriculture, additional research might apply inferential statistics and multivariate analyses to illuminate patterns across larger geographic scales, with sampling taking into account these important but geographically uneven processes.

In both Somotillo and Caballo Blanco, ultimate displacement is slow, as families are squeezed progressively from their land, driven by extractivism and re-concentration of land. Displaced individuals (migrants) at once can help families to stay on the land (subsistence migration) for more years but can also contribute to furthering the cycle of displacement, as we see in Caballo Blanco. Ultimately, for many families, the persistence of food insecurity suggests that migration can only delay the slow violence of the contemporary processes of agrarian change that lead to the displacement of semi-subsistence producers from the land.

Author Contributions: Conceptualization, L.C., C.R., B.S., R.J.; Methodology, C.R., B.S., L.C.; Data Analysis, C.R., L.C., B.S.; Data Collection, L.C., B.S., R.J.; Writing-Original Draft Preparation, L.C., B.S., C.R.; Writing-Review \& Editing, C.R., B.S., L.C., R.J.; Project Administration, C.R.; Funding Acquisition, C.R., L.C., B.S.

Funding: This research was funded by the National Science Foundation under grant number 1056811 (USA) and CONICYT-FONDECYT de Iniciación Folio 11170543 (Chile), and CONACYT-FORDECYT grant number 281987 (Mexico).

Acknowledgments: We are grateful to all of the participants of our study for sharing their experiences. We thank our field research assistants, Luis Ortega, Jesús Méndez, Enma López, Maria Rentería, José Joel Ordóñez Pineda, Santos Esteban Cruz Montoya, Justo Pastor Suazo, and Edwar Carias, for support in applying the survey and their thoughtful insights during fieldwork. We also thank Lisa Green, Juan Carlos Joo Chang, Rose Long, Juan Carlos Ocampo, and Andrés Zamudio for their assistance with data entry.

Conflicts of Interest: The authors declare no conflict of interest.

\section{References}

1. Labour Migration in Latin America and the Caribbean: Diagnosis, Strategy and ILO's Work in the Region; ILO Technical Reports; International Labour Organization: Lima, Peru, 2017; p. 134.

2. Orozco, M. Central American Migration: Current Changes and Development Implications; Inter-American Dialogue: Washington, DC, USA, 2018; p. 16.

3. Carte, L.; Radel, C.; Schmook, B. Subsistence migration: Smallholder food security and the maintenance of agriculture through mobility in Nicaragua. Geogr. J. 2019, 185, 180-193. [CrossRef]

4. Delgado Wise, R.; Márquez Covarrubias, H.; Puentes, R. Reframing the Debate on Migration, Development and Human Rights: Migration, Development, and Human Rights. Popul. Space Place 2013, 19, 430-443. [CrossRef] 
5. The State of Food Security and Nutrition in the World: Building Climate Resilience for Food Security and Nutrition; Food and Agriculture Organization of the United Nations: Rome, Italy, 2018; p. 202.

6. Bacon, C.; Sundstrom, W.; Flores Gómez, M.; Méndez, V.E.; Santos, R.; Goldoftas, B.; Dougherty, I. Explaining the "hungry farmer paradox": Smallholders and fair trade cooperatives navigate seasonality and change in Nicaragua's corn and coffee markets. Glob. Environ. Chang. 2014, 25, 133-149. [CrossRef]

7. Martí i Puig, S.; Baumeister, E. Agrarian policies in Nicaragua: From revolution to the revival of agro-exports, 1979-2015. J. Agrar. Chang. 2017, 17, 381-396. [CrossRef]

8. Grandia, L. Road Mapping: Megaprojects and Land Grabs in the Northern Guatemalan Lowlands. Dev. Chang. 2013, 44, 233-259. [CrossRef]

9. Alonso-Fradejas, A. Anything but a story foretold: Multiple politics of resistance to the agrarian extractivist project in Guatemala. J. Peasant Stud. 2015, 42, 489-515. [CrossRef]

10. Wittman, H.; Saldivar Tanaka, L. The agrarian question in Guatemala. In Promised Land: Competing Visions of Agrarian Reform; Rosset, P., Patel, R., Courville, M., Eds.; Food First Books: Oakland, CA, USA, 2006; pp. 23-40, ISBN 978-0-935028-28-7.

11. Aguilar-Støen, M. Beyond Transnational Corporations, Food and Biofuels: The Role of Extractivism and Agribusiness in Land Grabbing in Central America: Forum for Development Studies: Vol 43, No 1. Forum Dev. Stud. 2016, 43, 155-175. [CrossRef]

12. Guereña, A. Unearthed: Land, Power and Inequality in Latin America; OXFAM: Oxford, UK, 2016; p. 99.

13. Nixon, R. Slow Violence and the Environmentalism of the Poor; Harvard University Press: Cambridge, MA, USA, 2011; ISBN 978-0-674-04930-7.

14. Bakewell, O. Conceptualising Displacement and Migration: Processes, Conditions, and Categories. The Migration-Displacement Nexus: Patterns, Processes, and Policies; Berghahn Books: Oxford, MS, USA, 2011; pp. 14-28.

15. Oliver-Smith, A. Debating Environmental Migration: Society, Nature and Population Displacement in Climate Change. J. Int. Dev. 2012, 24, 1058-1070. [CrossRef]

16. Gemenne, F. Why the numbers don't add up: A review of estimates and predictions of people displaced by environmental changes. Glob. Environ. Chang. 2011, 21, S41-S49. [CrossRef]

17. Lunstrum, E. Green grabs, land grabs and the spatiality of displacement: Eviction from Mozambique's Limpopo National Park. Area 2016, 48, 142-152. [CrossRef]

18. Feldman, S.; Geisler, C. Land expropriation and displacement in Bangladesh. J. Peasant Stud. 2012, 39, 971-993. [CrossRef]

19. Granovsky-Larsen, S. Between the bullet and the bank: Agrarian conflict and access to land in neoliberal Guatemala. J. Peasant Stud. 2013, 40, 325-350. [CrossRef]

20. Jonas, S.; Rodríguez, N. Guatemala-U.S. Migration Transforming Regions; University of Texas Press: Austin, TX, USA, 2015; ISBN 978-0-292-76060-8.

21. USAID Guatemala. 2010. Available online: https://www.land-links.org/country-profile/guatemala/ (accessed on 28 February 2019).

22. Gauster, S.; Isakson, R. Eliminating market distortions, perpetuating rural inequality: An evaluation of market-assisted land reform in Guatemala. Third World Q. 2007, 28, 1519-1536. [CrossRef]

23. Lesser, G.; Batalova, J. Central American Immigrants in the United States. Migration Information Source. Available online: https://www.migrationpolicy.org/article/central-american-immigrants-united-states (accessed on 30 May 2019).

24. U.S. Agency for International Development. USAID Country Profile: Property Rights and Resources Governance, Nicaragua; USAID: Washington, DC, USA, 2011.

25. Broegaard, R. Land tenure insecurity and inequality in Nicaragua. Dev. Chang. 2005, 36, 845-864. [CrossRef]

26. Baumeister, E.; Fernández, E. Análisis de la Tenencia de la tierra en Nicaragua a Partir del Censo Agropecuario 2001; Ministerio de Agricultura, Ganaderia y Forestal, Instituto Nicaragüense de Estadisticas y Censos, and the Food and Agriculture Organization of the United Nations: Managua, Nicaragua, 2005.

27. IFAD. Republic of Nicaragua Country Strategic Opportunities Program; 2012. Available online: https: //webapps.ifad.org/members/eb/107/docs/EB-2012-107-R-11.pdf (accessed on 30 May 2019).

28. Overview. Available online: http://www.worldbank.org/en/country/guatemala/overview (accessed on 28 February 2019). 
29. Radel, C.; Schmook, B.; Carte, L.; Mardero, S. Toward a Political Ecology of Migration: Land, Labor Migration, and Climate Change in Northwestern Nicaragua. World Dev. 2018, 108, 263-273. [CrossRef]

30. Gourdji, S.; Läderach, P.; Valle, A.M.; Martinez, C.Z.; Lobell, D.B. Historical climate trends, deforestation, and maize and bean yields in Nicaragua. Agric. For. Meteorol. 2015, 200, 270-281. [CrossRef]

31. Rural Population (\% of Total Population)|Data. Available online: https://data.worldbank.org/indicator/sp. rur.totl.zs (accessed on 5 March 2019).

(C) 2019 by the authors. Licensee MDPI, Basel, Switzerland. This article is an open access article distributed under the terms and conditions of the Creative Commons Attribution (CC BY) license (http://creativecommons.org/licenses/by/4.0/). 